\begin{tabular}{|c|c|c|c|c|c|c|}
\hline \multirow{4}{*}{ Impact Factor: } & ISRA (India) & $=4.971$ & SIS (USA) & $=0.912$ & ICV (Poland) & $=6.630$ \\
\hline & ISI (Dubai, UAE & $=0.829$ & РИНЦ (Russia) & $=0.126$ & PIF (India) & $=1.940$ \\
\hline & GIF (Australia) & $=0.564$ & ESJI (KZ) & $=8.716$ & IBI (India) & $=4.260$ \\
\hline & JIF & $=1.500$ & SJIF (Morocco) & $=5.667$ & OAJI (USA) & $=0.350$ \\
\hline
\end{tabular}

\section{SOI: $1.1 /$ TAS $\quad$ DOI: $10.15863 /$ TAS \\ International Scientific Journal Theoretical \& Applied Science}

p-ISSN: 2308-4944 (print)

e-ISSN: 2409-0085 (online)

Year: 2020

Issue: 03

Volume: 83

Published: 25.03 .2020

http://T-Science.org
QR - Issue

QR - Article
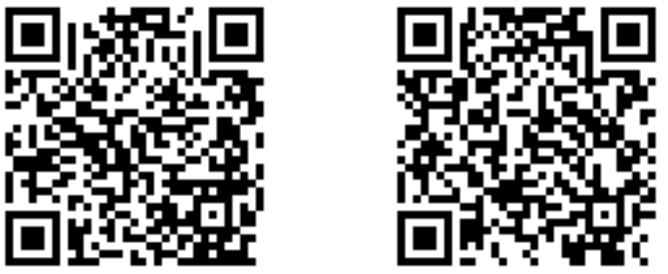

Nozimbek Nayimovich Zaripov

Bukhara State University

Teacher of the Department of Information Technology zaripov9898@mail.ru

\title{
USING METHODS OF FOREIGN EXPERIENCES IN TEACHING INFORMATICS AND INFORMATION TECHNOLOGIES IN SCHOOL
}

\begin{abstract}
The following article deals with analysis of ways in which programming languages are taught. Programming analysis of international educational institutions' teaching practices and the best ways to teach programs are offered. The use of advanced foreign experience in teaching programming languages to students, the role of digital technologies in programming and the understanding of robotic technologies will enhance classroom effectiveness. This article develops self-programming skills among high school students, helps to develop an interest in programming and help them find their place in the future, as well as create better programs for the development of the country.
\end{abstract}

Key words: digital technology, robotics, STEM, PIRLS, PISA, software, programming, application.

Language: English

Citation: Zaripov, N. N. (2020). Using methods of foreign experiences in teaching informatics and information technologies in school. ISJ Theoretical \& Applied Science, 03 (83), 111-114.

Soi: http://s-o-i.org/1.1/TAS-03-83-24 Doi: crossef https://dx.doi.org/10.15863/TAS.2020.03.83.24

Scopus ASCC: 3304.

\section{Introduction}

In the era of modern information technology, one of the key issues is the approach to teaching programming languages to students of secondary schools, the development of simplified methods and the assignment of tasks to students according to their age. The main goal of teaching computer science and information technology in secondary education is to educate young people in developing the knowledge, skills and abilities of working with modern informational technologies, to develop independent, logical and algorithmic thinking and to apply that knowledge. Today, software is being used in all areas. Whether it is our personal computer, TV set or airplane, we all have one or more computer programs. Computer programs determine the functionality of the devices installed on them and provide us with a way to control them. Computer programming is the process of designing, writing, testing and storing source code. The solution of the following problems will help to improve the quality of education: to attract students to programming languages, to develop knowledge and skills. There are some criteria for pupils' behavior during the process of the lesson: a) Pupils rely on a teacher. When working individually or in groups with students during a lesson, when students are asked questions, they remain silent and expect the teacher to tell the correct answer even when they know the correct answer. The pupil knows the correct answer, says the answer, but still wants the teacher to hear the answer. The teacher should minimize such situations during the lesson and teach the students to think independently, to express themselves freely and to build self-confidence.

b) Continuous preference for one or more students. During the lesson, it is evident that excellent students are always active, and unsatisfied students cannot fully master the lesson. This should not be allowed in computer science classes. All students should be given equal opportunity to participate actively in the class and allocate time appropriately.

c) Coming of pupils to the lesson without preparation. The first reason for this is that the teacher is not required by the teacher to complete the lessons, and the second is that the parents at home do not spend time with their child, complete the tasks, and they leave their daily grades uncontrolled. Another reason is that, pupils may not be prepared for 


\begin{tabular}{|c|c|c|c|c|c|c|}
\hline \multirow{4}{*}{ Impact Factor: } & ISRA (India) & $=4.971$ & SIS (USA) & $=0.912$ & ICV (Poland) & $=6.630$ \\
\hline & ISI (Dubai, UAE & $=0.829$ & РИНЦ (Russia & $=0.126$ & PIF (India) & $=1.940$ \\
\hline & GIF (Australia) & $=0.564$ & ESJI (KZ) & $=8.716$ & IBI (India) & $=4.260$ \\
\hline & JIF & $=1.500$ & SJIF (Morocec & $=5.667$ & OAJI (USA) & $=0.350$ \\
\hline
\end{tabular}

classes may be that they did not understand the theme. To avoid such situations, the teacher should be able to clearly explain the task, make sure every student understands the task, and give instructions on how to complete the task correctly.

d) Boring readers. Writing or lecturing traditionally in a notebook can make students more bored. Therefore, the use of modern information technology and new pedagogical technologies to make the lessons interesting, to explain the subject, taking into account the general interests of the classroom gives a good result.

The main objectives of computer science and information technology in secondary education are as follows:

- To provide students with knowledge on information and communication technologies and their application in practice;

- Successfully perform computer-assisted technology and key steps, to teach pupils to solve the exercises in order;

- Knowledge of algorithmic structures, basics of algorithmization and programming;

- To learn how to identify and apply computer software and capabilities;

- To develop students' mental development, to broaden their scientific outlook, to develop logical thinking;

- Formation of the core competencies that will enable them to maintain universal values through teaching the culture of the use of information and communication technologies that they will need to continue in the next stages of education.

Using STEM (science, technology, engeenering and mathematics - science, technology, engineering and mathematics) concepts, and the basic concepts of programming (logical methods, algorithms, based on advanced national and international experience in addressing the above tasks). STEM is a term used to combine academic disciplines. This term is often used in the selection of educational policies and school curricula to enhance competitiveness in science and technology development. This model of learning helps students not only acquire knowledge but also practice it. This will help young people to develop their knowledge and skills so that they can better adapt to their chosen profession in the future. STEM-based education promotes broad-based thinking, inspires news creation, and inspires world-class inventors.

In addition, there is a PISA system, which is widely used in foreign experience. The PISA system is an international program to assess student achievement in the field of education. These projects aim at assessing the creative and critical thinking of the students, their ability to apply what they have learned, and then encourage them to develop these skills. The program was launched in 1997 and is held every three years, first in 2000, with students from 43 countries testing their knowledge. In terms of years, there are students from 41 countries in 2003, 55 countries in 2006, 75 countries in 2009, 65 countries in 2012, 71 countries in 2015 and 78 countries in 2018. Every 3 years, one subject is allowed, and in 2000 the first reading literacy course was held, and in 2021 , mathematics literacy. It is precisely because the program is implemented among 15 -year-old students that at this age, most of the OECD countries are entering the final phase of compulsory education. What's more, this program is the only one in the world that measures the level of knowledge and skills of 15year-olds.

There is also a PIRLS system for assessing international literacy. PIRLS (Progress in International Reading Literacy Study is an international reading literacy assessment system) is an international evaluation system for elementary school students assessing the quality of reading and understanding. This test is designed to be held every 5 years. PIRLS provides fourth-graders' academic competence and international comparison of student achievement with regard to academic achievement and learning objectives and standards. PIRLS evaluates a comprehensive comprehension process for reading to focus on clearly articulated information, make correct conclusions interpret and combine ideas and information, as well as evaluate and critique content and text elements. In addition to reading assessment, the PIRLS schoolchildren, teachers and students collect home questionnaires on extensive information on contextual (sociological metthods) at home and at school regarding reading and learning. This valuable information includes information on how the education system is organized to facilitate reading: student housing and learning support; school climate and resources and how classes are usually conducted in the classroom.

By applying the above-mentioned foreign practices, teaching students in computer science and information technology can be effective in teaching students programming and programming languages.

Another innovative trend in modern software education is the study of algorithmic designs and programming methods in mobile application development. Smartphones and phones have attracted the attention and recognition of modern young people and will keep them interested in reading. Working in small groups at the school to develop mobile applications will increase students' motivation and self-reliance. This will help shape the current trends in teaching change in program content, forms and methods. These trends can be summarized by the following positions:

1) There is a need for students to use a project approach to master modern forms of software development;

2) Teamwork on project tasks, in addition to technical competence enables the development of 


\begin{tabular}{|c|c|c|c|c|c|c|}
\hline \multirow{4}{*}{ Impact Factor: } & ISRA (India) & $=4.971$ & SIS (USA) & $=0.912$ & ICV (Poland) & $=6.630$ \\
\hline & ISI (Dubai, UAE & $=0.829$ & РИНЦ (Russia & $=0.126$ & PIF (India) & $=1.940$ \\
\hline & GIF (Australia) & $=0.564$ & ESJI (KZ) & $=8.716$ & IBI (India) & $=4.260$ \\
\hline & JIF & $=1.500$ & SJIF (Morocec & $=5.667$ & OAJI (USA) & $=0.350$ \\
\hline
\end{tabular}

personal skills and competencies required in the modern labor market;

3) Using of software greatly enhances motivation for students' learning activities;

4) Using graphical applications and virtual environments in social relationships of students may help to solve learning problems in the learning process;

5) It is recommended to use the open-source online courses and distance learning systems (LMS) that provide openness, multimedia, interactivity and group work in the learning process;

6) The practical component and the interest of the learners can be achieved by incorporating training robotics and design elements into the lessons;

7) Construction of program-based training courses on mobile application development projects will increase the interest and activity of students, as well as ensure the effective nature of teaching.

To implement the above rules, it is possible to use the Internet platform, which will teach modern interactive technologies, virtualization and multimedia features. The most important subject is the use of interactive technologies in teaching programming languages to schoolchildren. An important direction to enhance the effectiveness of curriculum development for students is the organization of educational practices and understanding of interactive learning technologies as a tool for students' future professional activities. Through this, students will gain experience working with different programming methods. All computer technology that we use today is controlled by computer programs written to detect its behavior.

Significant changes are taking place in the modern education system to modernize the educational process. Teachers are more interested in continuing education and implementing projects using digital technologies. Schools classrooms are being well-equipped that teachers can support digital technology to teach a variety of subjects. The use of technology interactions enables research in all disciplines and at all levels of education.

An important component of the younger generation's digital literacy is the ability to understand and use data from digital technologies in a variety of formats. There is a need to develop ways in which innovation can be promoted to ensure more effective integration of digital technologies and improve the quality of the learning process. Using up-to-date devices will encourage students and motivation in this form of learning is based on the way student's use of tools (robots, vehicles, etc.) according to their suggestions. They programme certain functions, procedures and actions that must be performed by the device. The interconnection between software and hardware demonstrates how knowledge of the programming language can be put into practice (for example, automation and process management).

In conclusion, the use of advanced international experience in teaching computer science and information technology at school, enriching our understanding of digital literacy, and explaining technology to create educational robot platforms helps to increase students' interest in programming.

\section{References:}

1. Daly, T. (2011). Minimizing to maximize: An initial attempt at teaching introductory programming using Alice. Journal of Computer Science in Colleges, 26 (5), pp. 23-30., May, 2011.

2. Liu, M., Williams, D., \& Pedersen, S. (2002). Alien rescue: A problem-based hypermedia learning environment for middle school science. Journal of Educational Technology Systems, № 30 (3), pp. 255-270.

3. Werner, M. (2013). Teaching graphics programming on mobile devices. Journal of Computing Sciences in Colleges, pp.125-131.

4. Strijbos, J.-W. (2014). The effect of roles on computer-supported collaborative learning: doctoral dissertation. Heerlen, The Netherlands: Open University of the Netherlands.

5. Ala-Mutka, K. (2008). Problems in learning and teaching programming a literature study for developing visualizations in the CodewitzMinerva project. Institute of Software Systems, Tampere University of Technology, Finlandi.

6. William, L. (2013). Honig Teaching and Assessing Programming Fundamentals for Non Majors with Visual Programming //Computer Science: Faculty Publications and Other Works Faculty Publications. Loyola University Chicago, № 7.

7. Jordine, T., Liang, Y., \& Ihler, E. (2014). A mobile-device based serious gaming approach for teaching and learning Java programming. 


\begin{tabular}{|c|c|c|c|c|c|c|}
\hline \multirow{4}{*}{ Impact Factor: } & ISRA (India) & $=4.971$ & SIS (USA) & $=0.912$ & ICV (Poland) & $=6.630$ \\
\hline & ISI (Dubai, UAE & $=0.829$ & РИНЦ (Russia & $=0.126$ & PIF (India) & $=1.940$ \\
\hline & GIF (Australia) & $=0.564$ & ESJI (KZ) & $=8.716$ & IBI (India) & $=4.260$ \\
\hline & JIF & $=1.500$ & SJIF (Morocec & $=5.667$ & OAJI (USA) & $=0.350$ \\
\hline
\end{tabular}

IEEE Frontiers in Education Conference (FIE). Madrid, pp.1-5.

8. Nikitenko, Z.N.

(2019). Lichnostnorazvivajushhee inojazychnoe obrazovanie $v$ nachalnoj shkole. Monografija. 3-e izd. Moscow, Prometej.

9. Portes, P. R., \& Smagorinsky, P. (2010). Static structures, changing demographics: Educating teachers for shifting populations in stable schools. English Education, 42(3), 236-247.

10. Chao, X. (2016). Community service learning as critical curriculum: Promoting international students' second language practices. Critical Inquiry in Language Studies, 13(4), 289-318. 